\title{
MINEK A MESTERE?*
}

\author{
Józsa Zoltán ${ }^{1}$
}

Magyarország domborzati térképén a föváros szembeötlö dominanciája mellett sok apró pont jelzi a településszerkezetben a kistelepülések, falvak meghatározó szerepét. 1990-ben, a közjogi rendszerváltás hajnalán valamennyi magyar település visszakapta önállóságát és szabadon választhatta meg képviselöit és a település első számú vezetöjét, a polgármestert. Megannyi, szépen berendezett, jól müködő kis köztársaságvélték a politológusok, ahol majd virágzik a demokrácia, s a lakosok és képviselöik kartkarba öltve fáradhatatlanul munkálkodnak a település, a közösség jövőjén.

Sok minden történt azóta, $s$ az egyéni és a kollektív emlékezet példái között a sikertörténetek mellett ott vannak azok a tapasztalatok is, melyek, ha nem is általánosithatók, de jelzésértékkel birnak a jövöbeli fejlesztések, az önkormányzati rendszer korszerüsitése szempontjából.

A hétköznapok gyakran egyhangú ritmusát, unalmát csak ritkán töri meg egy-egy olyan híradás, mely elemi erővel irányítja a figyelmet a valóság olyan szeletére, mely egyébként a „dolgok hétköznapi rendje” szerint észrevétlen maradt volna.

Az elsö hir:

A magyar-ukrán-román határ közelében fekvő, alig 700 lakosú Túrricse több mint tíz éve hivatalban levő polgármestere a hírek szerint 2015 óta saját nyomtatású „utalvánnyal” fizette ki a közmunkásait, akiknek kötelező volt a polgármester által üzemeltetett szövetkezeti boltban az utalványt dupla áron levásárolni.

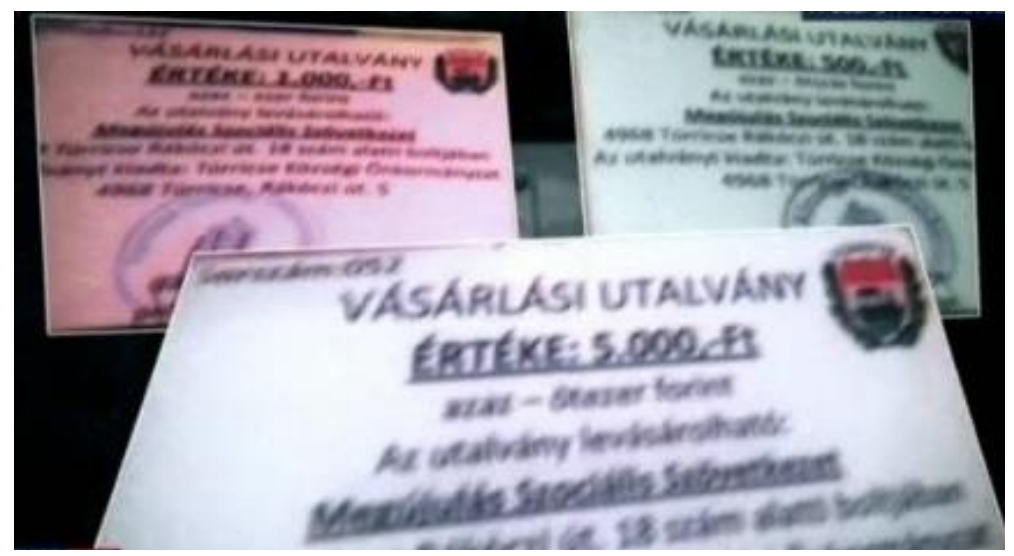

A kép forrása:

https://ezahir.hu/2017/04/07/botrany-a-szabolcsi-turricsen-szocialis-jegyben-kaptak-akozmunkasok-a-fizetesuket-amit-a-polgarmesterhez-kotheto-boltban-lehetett-csak-levasarolnihelyszini-riport/

\footnotetext{
${ }^{*}$ DOI 10.21867/KjK/2017.2.3.

${ }^{1}$ Dr. habil. Józsa Zoltán, egyetemi docens, SZTE ÁJK
} 


\section{A második:}

Budapest I. kerületének polgármestere közpénzből vásároltatott magának, állítólag személyes használatra két luxusautót, annak ellenére, hogy 200 méterre lakik hivatalától, s nem mellesleg jóval a piaci ár alatt bérel egy önkormányzati lakást. ${ }^{2}$

\section{A harmadik:}

Tomajmonostora polgármestere - állítólagos kapcsolatainak köszönhetően - nemcsak csak sikeres pályázó, hanem nagybirtokos is, aki a közmunkásokkal müvelteti földjét. ${ }^{3}$ Maga a közmunkaprogram egyébként müködőképesnek bizonyult a településen. Mégis, kik ezek a polgármesterek? Laikusok? Politikusok? Szakemberek? A közösség vagy az egyéni érdekek képviselői? S a kérdések még sorolhatók tovább.

Az önkormányzati törvény elfogadása óta gyakorlatilag nincsenek különös feltételei a polgármesteri tisztség betöltésének. Bárki, magyar állampolgárság, választójog és büntetlen előélet birtokában ringbe szállhat a tisztség elnyeréséért. 2004 óta általánossá vált a polgármester közvetlen választása is, mely a társadalmi támogatás egyfajta mutatója.

A megállapítás formális igazsága (in put demokrácia) mellett ugyanakkor nem hagyható figyelmen kívül az a tény, hogy a támogatás egyfelöl függ a választáson résztvevők számától, másfelől pedig a valódi legitimitás forrása nem a választás egyszerű aktusa, hanem a közösség érdekében végzett, s mérhető eredményekben összesíthető teljesítmény (out put demokrácia). Nem mellesleg Európa számos országában vagy a testület választja (Franciaország), vagy a központi kormány nevezi ki (Hollandia) a polgármestert. Ennek ellenére nincs igazolható kapcsolat a tisztség betöltésének módja és a polgármester eredményessége, elfogadottsága között.

Fel kell ismernünk, s ki kell mondanunk tehát, hogy a polgármester is csak egy a polgárok közül, sem nem jobb, sem nem más, mint a választók többsége, közülünk való. Így mindenféle kiváltságokkal, előjogokkal, prerogratívákkal való felruházása nemcsak veszélyes, hanem téves is.

A jogalkotó a normatív szabályozás elvontsága okán azonos rendelkezéseket fogalmazott meg a különböző településtípusok (falvak, városok, kerületek, főváros és megyék) első számú vezetői számára. Pedig a települések lakosságszáma, gazdasági, társadalmi, kulturális sajátosságai, intézményhálózata stb. döntően meghatározza az önkormányzatnak a helyi közösség életében betöltött szerepét, s nem utolsó sorban a település vezetőjének, a polgármesternek a feladatait is. A SZMSZ-ek elvileg lehetőséget adnak a helyi sajátosságok érvényesítésére, mégis a sorvezetőtől való eltérés inkább kivétel, mintsem föszabály. Egyébiránt a gyakorlat (az élet) is felülírja rendszerint az elvont szabályokat.

2 A hírt bővebben és a Budavári Önkormányzat válaszlevelének közlését lásd itt: https://mno.hu/belfold/draga-mulatsag-a-polgarmester-kenyelme-2398170 (letöltés ideje: 2017. május 10.)

${ }^{3}$ https://mno.hu/belfold/csaszarkent-viselkedik-a-fideszes-polgarmester-2394809 (letöltés ideje: 2017. május 10.) 
Ami a feladatok számottevő differenciái ellenére is közös elvárás, az a közösség, a választók érdekeinek maradéktalan képviselete. Mindez azt is jelenti, hogy egyéni érdekek sohasem helyezhetők a közösség szolgálata elé.

Nem szükséges a magyar önkormányzati rendszer immáron több mint negyedszázados történetének mélyebb ismerete azon felismeréshez, hogy a képviselői tevékenység mellett a polgármesteri tisztség is foglalkozássá vált, a szó hétköznapi értelmében, $\mathrm{s}$ a folyamat szükségszerüen vonta maga után a tisztséget több cikluson keresztül betöltő személyek megválasztását.

Mint minden változásnak, ennek is számtalan értelmezési lehetősége adódik. A személyi folytonosság kedvezően hathat a szakmaiság erősödésére, a településvezetés, a város irányítás komplex ismereteket követelő feladatának magas szintü ellátására. Ugyanakkor, mint ahogy a fenti példák is illusztrálják, a jogi szabályozás hézagossága, adott esetben hiánya (visszahívás), valamint a felügyeleti, ellenőrzési eszközök alkalmazásának esetlegessége lehetőséget kínálhat a jogszabályok kijátszására, a hatalommal való visszaélésre.

Valljuk meg őszintén, akár a testületek, akár a polgármesteri döntések közvetlen lakossági ellenőrzésének a lehetősége csekély, már csak a képviselők és a képviseltek közötti információs asszimetria kiküszöbölhetetlennek tünő akadálya miatt is. Az ezzel kapcsolatos demokratikus illúzióinkkal végérvényesen fel kell hagynunk, éppúgy, mint a pártpolitika befolyásának felszámolására irányuló hol erősebb, hol gyengébb törekvésekkel. A magyar önkormányzati rendszer végletesen átpolitizálódott, gyakran a kistelepüléseken is.

\section{1. táblázat}

Polgármesterek illetménye a település lakosságszáma alapján

\begin{tabular}{|c|c|c|}
\hline $\begin{array}{c}\text { Település } \\
\text { lakosságszáma }\end{array}$ & $\begin{array}{l}\text { Polgármesterek } \\
\text { illetménye } \\
\text { 2014-ben }\end{array}$ & $\begin{array}{l}\text { Polgármesterek } \\
\text { illetménye } \\
\text { 2016-ban }\end{array}$ \\
\hline 500 fö és az alatt & $149800 \mathrm{Ft} / \mathrm{hó}$ & 199434 Ft/hó \\
\hline $501-1500$ fö & \multirow{3}{*}{$299600 \mathrm{Ft} / \mathrm{hó}$} & $199434 \mathrm{Ft} / \mathrm{hó}$ \\
\hline $1501-2000$ fö & & $498585 \mathrm{Ft} / \mathrm{hó}$ \\
\hline $2001-5000$ fö & & $548443 \mathrm{Ft} / \mathrm{hó}$ \\
\hline 5001-10 000 fö & $449400 \mathrm{Ft} / \mathrm{hó}$ & $598302 \mathrm{Ft} / \mathrm{hó}$ \\
\hline $10001-30000$ fö & $524300 \mathrm{Ft} / \mathrm{hó}$ & $698019 \mathrm{Ft} / \mathrm{hó}$ \\
\hline 30000 fö felett & $599200 \mathrm{Ft} / \mathrm{hó}$ & $797736 \mathrm{Ft} / \mathrm{hó}$ \\
\hline
\end{tabular}

Forrás: 24.hu

Ezt mi sem bizonyítja jobban, hogy a múlt év végén a kormány újfent elérkezettnek látta az időt - az önkormányzati érdekképviseletek, szövetségek számottevő nyomása mellett - arra, hogy az önkormányzati törvény módosítása révén rendezze a polgármesterek illetményét. ${ }^{4} \mathrm{Az}$ "újfent" kitétel jogosságát a kormány 2014-ben végrehajtott korrekciója alapozza meg, mely akkoriban éppenséggel csökkentette a helyi

\footnotetext{
${ }^{4}$ T/13270. számú törvényjavaslat, kihirdetve a 2016. évi CLXXXV. törvénnyel
} 
vezetők juttatását (az eltéréseket az 1. táblázat mutatja). A jogszabály a korábbiakhoz képest differenciáltabb településkategóriák mentén határozza meg az elérhetö jövedelmet az államtitkári illetmény meghatározott százalékában. A norma egyedüli rendező elve a lakosságszám, ami vajmi keveset mond az adott település polgármesterének tényleges feladatairól.

Így aztán, nem minden alap nélküliek a feltevések - közeledvén a választások időpontjához - hogy politikai, mintsem szakmai döntés született a kormány részéről. Kétségtelen, hogy a települések vezetöi politikai tényezőként jelentős érdekérvényesítési potenciállal bírnak, ugyanakkor megváltozott az önkormányzati feladatok struktúrája is.

Végső soron az igazi alapkérdések - mint ahogy korábban is - nyitva maradtak. A közel 3200 önkormányzat jelentős része kistelepülésen müködik, melyek feladat-és hatásköre az oktatás és az egészségügy államosítása, valamint az államigazgatási funkciók egy részének a járásokhoz történő telepítése miatt minimalizálódott. A megvalósult hivatali integráció után a napirend következő pontja a települési integráció lehet, mely egyben megoldást nyújthat a tisztséghez kapcsolódó szakmai, pénzügyi, szervezeti és más nyitott kérdésekre is.

Történjék bármi, az intézmény valódi súlyát és tekintélyét csak akkor őrizheti meg, ha a polgármester a közérdek, a széles értelemben vett közakarat képviselője és megtestesítője marad, példát mutatva a választók számára.

Források:

- https://mno.hu/belfold/draga-mulatsag-a-polgarmester-kenyelme-2398170

- https://mno.hu/belfold/csaszarkent-viselkedik-a-fideszes-polgarmester2394809

- https://ezahir.hu/2017/04/07/botrany-a-szabolcsi-turricsen-szocialis-jegybenkaptak-a-kozmunkasok-a-fizetesuket-amit-a-polgarmesterhez-kotheto-boltbanlehetett-csak-levasarolni-helyszini-riport/

- T/13270. számú törvényjavaslat

- 2016. évi CLXXXV. törvény 